Jan Charles Horrow MD, Donald H. Lambert PH D MD

\title{
The search for an optimal interval between pretreat- ment dose of d-tubocurarine and succinylcholine
}

A study was conducted to determine the optimal interval between the administration of $d$-iubocurarine (dTc) ard succinylcholine ( $S C h$ ) with regard to onset and duration of neuromuscular block and presence of fasciculations and postoperative myalgias.

Forty female patients received dTc $3 \mathrm{mg} \cdot 70 \mathrm{~kg}^{-1}$ prior to SCh $1.5 \mathrm{mg} \cdot \mathrm{kg}^{-1}$. The interial between drugs was 0.1 . 3, 5, or 7 minutes. Transduced thumb adduction recorded block onset and recovery. Fasciculations were visually detected. Myalgias were assessed on posfoperative interview.

Pretreatment interval did not affect the anset or recovery of neuromuscular block. Postoperative myalgias were also independent of pretreament timing. Fasciculations were blocked with 3, 5, or 7 minute intervals, but not with 0 or 1 minute intervals. Therefore, three minutes appear to be the optimal time interval between administration of $d T C$ and $S C h$ since shorter intervals do not inshibit fasciculations and tonger intervals do not afford any additionat advanteges.

\section{Key words}

NEUROMUSCULAR RELAXANTS: d-tubocurarine, succinylcholine; MUSCLE RELAXANTS: fasciculation.

From the Department of Anesthesia, Brigham and Women's Hospital, Harvard Medical School, Boston, Massachusetts.

Address correspondence to: Dr. Jan Charlcs Horrow, Department of Anesthesia, 75 Francis Street, Boston, MA 02115 .
Pretreatment drugs are given prior to succinylcholine ( $\mathrm{SCh}$ ) to prevent or diminish its side effects. The claimed benefits of pretreatment include attenuated rises in intra-ocular, intra-gastric, and intra-cranial pressures, decreased rises in serum potassium concentration, and a decreased incidence and severity of fasciculations and postoperative myalgias.

Agents used for pretreatment include small doses of $\mathrm{SCh},{ }^{1}$ lidocaine, ${ }^{2,3}$ diazepam, ${ }^{4-6}$ vitamin $\mathrm{C}{ }^{7}$ and the nondepolarizing muscle relaxants. ${ }^{8-12}$ Whereas numerous investigations have explored the efficacy of the nondepolarizing relaxants, little attention has been directed to the optimum time interval between administration of the pretreatment agent and $\mathrm{SCh}$.

While three minutes is commonly taught as the appropriate time interval between non-depolarizing tclaxant and $\mathrm{SCh}$, the authors have noted that practicing anaesthetists pay little regard to the exact timing. As a result, intervals range from a few seconds to over ten minutes with apparent clinical success, but without documentation in the literature.

Only one study compared onset and recovery from paralysis with two different time intervals; ${ }^{8}$ no difference was found. However, the data may not be valid because crude measurement techniques were employed. In addition that study lound a delayed onset and no hastening of recovery of block with pretreatment, the opposite of what subsequent multiple investigations have concluded. For these reasons, the authors re-examined the issue of pretreatment timing interval.

We studied the effects of a varying interval 
between administration of $d$-tubocurarine (dTc) and $\mathrm{SCh}$ on the onset of paralysis, the recovery from paralysis, the occurrence of fasciculations, and the frequency of postoperative myalgias. We hoped to find an optimal time interval for the parameters measured, or validate the practice of total disregard for the interval.

\section{Methods}

This investigation was approved by our institution's Committee for the Protection of Human Subjects from Research Risks.

Forty nonpregnant female patients who were to undergo gynecologic surgery or knee arthroscopy were divided randomly into five groups of eight patients. All patients were of ASA physical status clessification I or II. No patient had a history of neurologic or muscular disease or received medications known to interact with muscle relaxants. Each patient received an induction dose of thiopentone intravenously and nitrous oxide in oxygen by face mask, and intravenous narcotic or barbiturate as needed to maintain anaesthesia. Halogenated anaesthetics were not administered.

After induction of anaesthesia, force of thumb adduction at the proximal phalanx was measured with a Grass FT 10 transducer. The ulnar nerve was stimulated at the wrist with supramaximal pulses of 200 microsecond duration at one second intervals. Use of $1 \mathrm{~Hz}$ stimuli permitted more precise determination of the onset of block, compared with slower rates of stimulation. While data collected using I $\mathrm{Hz}$ stimuli may differ from those using other rates, all comparisons among the data remain valid; thus the additional precision afforded by $1 \mathrm{~Hz}$ justifies its use.

When a suitable baseline twitch was obtained on a Grass Model 7 polygraph, d-tubocurarine 0.043 $\mathrm{mg} \cdot \mathrm{kg}^{-1}\left(3 \mathrm{mg} \cdot 70 \mathrm{~kg}^{-1}\right)$ was injected into a rapidly flowing intravenous line. Group A patients received $\mathrm{SCh} 1.5 \mathrm{mg} \cdot \mathrm{kg}^{-1} \mathrm{IV}$ immediately after dTc. Other groups received $S C h 1.5 \mathrm{mg} \cdot \mathrm{kg}^{-1}$ IV after a specified interval: one minute for group $B$, three minutes for Group $\mathrm{C}$, five minutes for Group D, and seven minutes for group $\mathbf{E}$. Twitch tension was recorded continuously until complete recovery from $\mathrm{SCh}$ was achieved.

After administration of succinylcholine, the patient's eyes, neck, and extremities were observed for the presence of fasciculations. Fasciculations were classified as follows: none $=$ no visible fasciculations; mild = fine fingertip motion or moderate palpebral motion; moderate $=$ minimul contractions at the neck or extremities; severe vigorous contractions at the neck or extremities. Upon disappearance of twitch tension, laryngoscopy and tracheal intubation were performed. The presence or absence of jaw relaxation and any motion of the vocal cords were noted by the anaesthetist.

Polygraph recordings were analyzed to determine the time from administration of $\mathrm{SCh}$ to $95 \mathrm{per}$ cent twitch depression, and the times from administration of SCh to 25 per cent recovery and 75 per cent recovery of twitch tension.

All patients were interviewed by one of the authors between 24 and 48 hours postoperatively. Each patient was asked, "Do you have any discomfort?" Then, "Do you have any aches or pains?" Postoperative myalgias were judged present or absent based upon the subsequent discussion. Discomfort from diaphragmatic irritation from residual gas insufflated during laparoscopy was excluded.

Groups were examined for differences in age, body weight, kind of surgery, fasciculation score, incidence of postoperative myalgias, time to 95 per cent block, time to 25 per cent recovery, time to 75 per cent recovery, and 25 per cent-75 per cent recovery time. Analysis of variance or the Chisquare contingency test was used. Differences were deemed significant if at the $p<0.05$ level. Fasciculation data were subjected to the Jonckheere-Terpstra nonparametric test for ordered alternatives. ${ }^{13}$

\section{Results}

Each group contained eight patients. The groups were similar with respect to age, body weight, and kinds of surgery (Table I). All patients had adequate jaw relaxation and motionless vocal cords during laryngoscopy. All patients were ambulating by the first postoperative day.

Times to onset of paralysis and recovery from neuromuscular block appear in Table II. The groups did not differ in time to 95 per cent block, time to 25 per cent recovery, time to 75 per cent recovery, or time from 25 per cent to 75 per cent recovery.

Fasciculation scores appear in Table III. The Jonckheere-Terpstra test showed a decreasing severity of fasciculations with increasing interval 
TABLE 1 Patient demographic data

\begin{tabular}{llllll}
\hline $\begin{array}{l}\text { Group } \\
\text { Interval (mins) }\end{array}$ & A & $B$ & $C$ & $D$ & $E$ \\
\hline Age (years)* & 0 & $l$ & 3 & 5 & 7 \\
Weight (kg)* & $31 \pm 6$ & $42 \pm 21$ & $39 \pm 13$ & $38 \pm 10$ & $30 \pm 8$ \\
Kind of Surgery: & $70 \pm 16$ & $61 \pm 10$ & $62 \pm 13$ & $60 \pm 6$ & $60 \pm 10$ \\
Laparotomy & 2 & 3 & 1 & 1 & 3 \\
Vaginal hysterectomy & 1 & 0 & 1 & 1 & 0 \\
Arthroscopic (knee) & 0 & 1 & 0 & 1 & 0 \\
Laparoscopic & 5 & 4 & 6 & 5 & 5 \\
\hline
\end{tabular}

Mean $=\mathrm{SD}(\mathrm{N}=8) \mathrm{p}=\mathrm{NS}$ ameng groups.

Entries are number of patients.

between $\mathrm{dTc}$ and SCh significant at the $\mathrm{p}<0.001$ level.

Despite the difference in fasciculations, the groups did not differ significantly in the incidenco of postoperative myalgias $\left(\chi^{2}=1.4, p=N S\right)$.

Patients in each group were divided into two categories: those who underwent minor surgery (arthroscopic or laparoscopic) and those who underwent major surgery (vaginal hysterectomy or laparotomy). Two-way analysis of variance applied to the frequency of myalgias in each subgroup disclosed no effect of type of surgery or of interval of drug administration on frequency of myalgias.

\section{Discussion}

Several publications have addressed the effects of pretreatment on the onset and recovery of neuromuscular blockade. Table IV summarizes their features. The methods of these various studies differ in the use of halogenated anaesthetics, in stimulus frequency, in the technique of neuromuscular blockade measurement, in the dose of $\mathrm{SCh}$, and in the interval between $\mathrm{dTc}$ and SCh. Nevertheless, the studies show considerable agreement in the effects on onset and recovery of block.
TABLE III Fasciculation scones and myalgia frequency

\begin{tabular}{|c|c|c|c|c|c|}
\hline $\begin{array}{l}\text { Group } \\
\text { interval (min) }\end{array}$ & $\begin{array}{l}A \\
0\end{array}$ & $\begin{array}{l}B \\
1\end{array}$ & $\begin{array}{l}C \\
3\end{array}$ & $\begin{array}{l}D \\
5\end{array}$ & $\begin{array}{l}E \\
7\end{array}$ \\
\hline \multicolumn{6}{|c|}{ Fasciculation score:* } \\
\hline none & 0 & 1 & 5 & 6 & 7 \\
\hline mild & 0 & 4 & 3 & 2 & 1 \\
\hline moderate & 1 & 3 & 0 & 0 & 0 \\
\hline severe & 7 & 0 & 0 & 0 & 0 \\
\hline \multicolumn{6}{|l|}{ Myalgia:* } \\
\hline present & 4 & 3 & 3 & 2 & 3 \\
\hline absent & 4 & 5 & 5 & 6 & 5 \\
\hline
\end{tabular}

*Number of patients.

\section{Paralysis times}

Pretreatment does not affect the onset of neuromuscular block. ${ }^{11,14,15}$ Only Cullen's study" disagrees; this might be explained by the fact that Cullen did not measure twitch tension. Our results indicate no effect of intervals of $0,1,3,5$, or 7 minutes on onset of block.

Recovery from paralysis is hastened by pretreatment with dic if the SCh dosc is not increased. ${ }^{11,14-16}$ When SCh dose is increased with pretreatment, recovery from paralysis is not affec-

TABLE II Twitch tension data

\begin{tabular}{|c|c|c|c|c|c|c|}
\hline $\begin{array}{l}\text { Group } \\
\text { Interval (min) }\end{array}$ & $\begin{array}{l}A \\
0\end{array}$ & $\begin{array}{l}B \\
l\end{array}$ & $\begin{array}{l}C \\
3\end{array}$ & $\begin{array}{l}D \\
5\end{array}$ & $\begin{array}{l}E \\
7\end{array}$ & $p$ \\
\hline Time to $95 \%$ Block (sec) & $55 \pm 14^{*}$ & $42 \pm 7$ & $43 \pm 19$ & $41 \pm 12$ & $40 \pm 9$ & NS \\
\hline Time to $25 \%$ Recovery (sec) & $465 \pm 59$ & $527 \pm 150$ & $505 \pm 67$ & $453 \pm 79$ & $571 \pm 149$ & NS \\
\hline Time to $75 \%$ Recovery (sec) & $560 \pm 77$ & $628 \pm 179$ & $608 \pm 69$ & $546 \pm 101$ & $6.56 \pm 164$ & NS \\
\hline Time from $25 \%$ to $75 \%$ Recovery (sec) & $95 \pm 24$ & $101 \pm 32$ & $103 \pm 21$ & $93 \pm 31$ & $85 \pm 19$ & NS \\
\hline
\end{tabular}

*Mean $\pm \mathrm{SD} ; \mathrm{N}=8$ for all entries. 
TABLE IV Summary of some previous studies of pretreatment with d-fubocurarinc

\begin{tabular}{|c|c|c|c|c|c|c|c|}
\hline \multirow[b]{2}{*}{ Authors } & \multirow{2}{*}{$\begin{array}{l}\text { Stimulus } \\
\text { frequency } \\
(\mathrm{Hz})\end{array}$} & \multirow{2}{*}{$\begin{array}{l}\text { Measure- } \\
\text { ment } \\
\text { techniciue }\end{array}$} & \multirow[b]{2}{*}{$\begin{array}{l}\text { Interval } \\
\text { (min) }\end{array}$} & \multirow[b]{2}{*}{$\begin{array}{l}\text { Dase } \\
\text { SCh }\end{array}$} & \multicolumn{2}{|c|}{ Effect of pretrectment on } & \multirow[b]{2}{*}{ Comments } \\
\hline & & & & & $\begin{array}{l}\text { Onset of } \\
\text { block }\end{array}$ & $\begin{array}{l}\text { Recovery } \\
\text { of block }\end{array}$ & \\
\hline Walts and Dillon 14 & 0.25 & TTA & 3 & $40 \mathrm{mg} \cdot \mathrm{m}^{-2}$ & Nut studied & Hastented & 1\% Halullane \\
\hline Miller and Way's & 0.25 & TTA & 3 & $1 \mathrm{mg}^{-\mathrm{kg}^{-1}}$ & None & Hastened & \\
\hline Cullen ${ }^{\mathbf{B}}$ & 0.25 & FF & $\begin{array}{l}3 \\
7\end{array}$ & $\begin{array}{l}1 \mathrm{mg} \cdot \mathrm{kg}^{-1} \\
1.5 \mathrm{mg} \cdot \mathrm{kg}^{1}\end{array}$ & $\begin{array}{l}\text { Delayed } \\
\text { None* }\end{array}$ & $\begin{array}{l}\text { None } \\
\text { None }\end{array}$ & $\begin{array}{l}\text { *Compared with control } \\
\text { group (SCh I mg } \mathrm{kg}^{-1} \text { ) }\end{array}$ \\
\hline Freund and Rubin ${ }^{16}$ & 0.25 & TTA & $\begin{array}{l}4 \\
4\end{array}$ & $\begin{array}{l}0.7 \mathrm{mg} \cdot \mathrm{kg}^{-1} \\
1.2 \mathrm{mg} \cdot \mathrm{kg}^{-1}\end{array}$ & $\begin{array}{l}\text { Not studied } \\
\text { Not studicd }\end{array}$ & $\begin{array}{l}\text { Hastened } \\
\text { Nonet }\end{array}$ & $\begin{array}{l}\text { 'Compared with control } \\
\left.\text { (SCh } 0.7 \mathrm{mg} \cdot \mathrm{kg}^{1}\right)\end{array}$ \\
\hline Blitt et al." & 0.25 & TTA & $>3$ & $1.5 \mathrm{mg} \cdot \mathrm{kg}^{-1}$ & None & Hastened $\ddagger$ & $\begin{array}{l}\text { ¥Comparcd with SCh } \\
1.5 \mathrm{mg} \cdot \mathrm{kg}^{-1} \text { control; no effect } \\
\text { compared with } \$ \mathrm{Ch} 1 \mathrm{mg} \cdot \mathrm{kg} \\
\text { control }\end{array}$ \\
\hline
\end{tabular}

TTA = Transduced Thumb Adduction. FF = Observed Finger Flexion

ted. ${ }^{11,16}$ Again, Cullen's study differs. ${ }^{8}$ Although Cullen found no difference between recovery times for three-minute and seven-minute intervals, the authors expected to uncover an effect of interval utilizing twitch tension measurement and intervals as diverse as zero and seven minutes. In particular, we expected group A (zero minutes) patients to demonstrate more rapid recovery, as if they had received SCh without $\mathrm{dTc}$. No such effect was found, indicating that the hastening effect o[ dTe on recovery of SCh block is present even when dTc and SCh are administered simultaneously. We did not investigate administration of $\mathrm{dTc}$ after SCh to shorten the duration of $\mathrm{SCh}$ block; our results suggest this as a possibility, however.

\section{Fasciculations}

Virtue ${ }^{12}$ examined the efficacy of pretreatment in blocking fasciculations using either a 30 -second or 60 -second time interval. SCh $60 \mathrm{mg} \cdot 70 \mathrm{~kg}^{-1}$ was given after dTc $4.5 \mathrm{mg}$. Overall, 32 per cent of his patients displayed fasciculations, 30 per cent in the 30 -second group and 35 per cent in the 60-second group $(p=N S)$. Our results differ: only 1 of 16 patients in our groups $A$ and $B$ had no visible fasciculations. We attribute this to the larger dose of SCh and smaller dose of $\mathrm{dTc}$ employed in the current study, as well as to the different time intervals. To prevent fasciculations, there is no advantage in waiting longer than three minutes, and some advantage to waiting more than one minute, according to our results.

\section{Myalgias}

Pretreatment interval did not affect the frequency of postoperative myalgias. Based on the difference in fasciculations among groups, one might expect myalgias to be more common in groups $\mathrm{A}$ and $\mathrm{B}$. Several phenomena may explain the absence of myalgias despite moderate to strong fasciculations. First, lack of correlation of fasciculations with myalgias is common. ${ }^{17}$ Second, some factors known to affect myalgias were not controlled in this study: duration of operation, ${ }^{18}$ patient position, ${ }^{119}$ and the time, amount, and frequency of injection of thiopentone. ${ }^{20}$ Third, dTc may protect the patient from myalgias even when administered zero or one minute prior to SCh. It is noteworthy, however, that dTc administered subsequent to $\mathrm{SCh}$ is ineffective in this regard. ${ }^{21}$

The authors selected a control group for this study from these choices: omission of pretreatment dose without modifying $\mathrm{SCh}$ dose; omission of pretreatment dose with reduction of SCh dosc; and, not altering any relaxant drug dose but using a zero time interval.

The first choice is unsuitable because the hastening of recovery from paralysis by pretreatment ${ }^{11.14-16}$ will confound comparisons intended to examine the effect of interval alone. The second choice complicates matters in that different doses of SCh alone might affect onset of block, severity of fasciculations, or presence of myalgias. This study investigates the effects of pretreatment interval, not the effects of pretreatment itself; thus, the third 
choice of control group was selected, one with an interval of zero minutes.

A limitation of this investigation is its singleblinded nature. However, knowledge by the in vestigator of group assignments could not affect the twitch data collected by polygraph. Also, fasciculation scores were defined in a manner sufficiently rigid to permit little room for interpretation and thus little investigator bias. Myalgia data are more susceptible to investigator bias. The lack of a significant effect of interval on myalgias despite an effect on fasciculations, and the agreement of this finding with previuusly published reports ${ }^{17}$ suggests validity of the myalgia data despite absence of a double-blinded design.

In summary, this study realfirmed the time constraints for blocking fasciculations already known: the incidence and severily of fasciculations is reduced when the interval berween $\mathrm{dTc}$ and $\mathrm{SCh}$ is three minutes or greater.

However, neitluer onset nor recovery of block varied with intervals ranging from zero to seven minutes. With respect to paralysis and myalgias, there is no optimum interval: simultaneous drug administration will suffice. However, if anaesthetists prefer to avoid fasciculations, a three-minute interval is superior to shorter ones; longer intervals offer no additional benefit.

\section{Acknowledgment}

The authors thank Ms. Judy Wyman for manuscript preparation.

\section{References}

1 Baraka A. Self-taming of succinylcholine-induced fasciculations. Anesthesiology 197?; 46: 292.

2 Usubiaga JE. Wikinski JA, Usubiaga LE, Molina $F$. Intravenous lidocaine in the prevention of postoperative muscle pain by succinylcholine administration. Anesth Analg 1967; 46: 225.

3 Haldia $K N$. Chatterji $S$, Kackar $S N$. Intravenous lignocaine for prevention of muscle pain after succinylcholine. Anesth Analg 1973; 52: 849.

4 Fahmy NR, Malek NS, Lappas DG. Diazepam prevents some adverse effects of succinylcholine. Clin Pharmacol Ther 1979; 26: 395.

5 Verma RS, Chatterji S, Mathur N. Diazepam and succinylcholine-induced muscle pains. Anesth Analg 1978; 57: 295

6 Erkola O. Salmenpera $M, T a m m i s t o ~ T$, Does diaze- pam pretreatment prevent succinylcholine induced fasciculations? A double-blind comparison of diazcpam and tubocurarine pretreatments. Anesth Analg 1980; 59: 932 .

7 Gupte SR, Savant NS. Post suxancthoniun pains and vitamin C. Anaesthesia 1971;26: 436

8 Cullen DJ. The effect of pretreatment with nonde polarizing muscle relaxants on the neuromuscular blocking action of succinylcholine. Anesthesiology 197I; $35: 572$.

9 Bennett EJ, Montgonery SJ, Dalal FY, Raj PP. Pancuronium and the fasciculations of succinylcholine. Anesth Antug 1973; 52: 892

10 Domaoal AM, Weniger FC, Wolfson B. "Precurarization" using pancuronium. Anesth Analg 1975; 54: 71

11 Blitt $C D$, Carlson $G L$, Rolling $G D$, Homeroff $S R$, Otto $C W$. A comparative evaluation of pretreatment with nondepolarizing neuromuscular blockers prior to the administration of succinylcholine. Anesthesio$\log y$ 1981; 55: 687 .

12 Virtue RW. Comparison of gallamine with d-tubocurarine effects on fasciculations after succinylcholine. Anesth Analg 1975; 54: 81 .

13 Hollander H, Wolfe DA. Nonparametric Statistical Methods. New York: Wiley, 1973; 120.

14 Walts $L F$, Dillon JB. Clinical studies of the interaction between d-tubocurarine and suecinylcholine. Anesthesiology 1969; 31: 39.

15 Miller $R D$, Way WL. The interaction between succinylcholine and sub-paralyzing doses of d-tubocurarine and gallamine in man. Anesthesiology 1971; 35: 567 .

16 Freund FG, Rubin AP. The need for additional succinylcholine after d-tubocurarine. Anesthesiology 1972; 36: 185.

17 Collier $C B$. Suxamethonium fasciculations: A topographical study. Anaesth Intensive Care 1980; 8:26.

18 Brodsky JB, Ehrenwerth J. Postoperative muscle pains and suxamethonium. Br J Anaesth 1980;52 215.

19 Crawford JS. Suxamethonium muscle pains and pregnancy. Br J Anaesth 1971; 43:677.

20 Craig HJL. The protective effect of thiopentone against muscular pain and stiffness which follows the use of suxamethonium chloride. Br J Anaesth 1964; 36: 612

21 Morris DDB, Dunn CH. Suxamethonium chloride administration and post-operative musele pain. $\mathrm{Br}$ Med J 1957; 1: 383. 


\section{Résumé}

On a cherché à déferminer l'intervalle idéal à maintenir entre l'administration préventive de la d-tubocurarine (dTC) et celle de la succinylcholine (SCh), intervalle qui permettrait de conserver la rapidité d' installation du bloc nearomusculaire et sa duree tout en minimisant les fasciculations et les myalgies post-opératoires.

$L^{\prime}$ étude a porté sur 40 patientes ayant reģa $3 \mathrm{mg} 70$ $\mathrm{kg}^{-1}$ de dTc avant l'administration de $1.5 \mathrm{mg} \cdot \mathrm{kg}^{-1} \mathrm{SCh}$. Les patientes ont été réparties en groupes où l' intervalle entre l'aiministration des médicaments a été de 0, 1,3, 5 , et 7 minutes. La mesure de l'adduction di pouce par transducteur monitorait " installation et la disparition du bioc neuromusculaire. Les fasciculations étaient observées visuellement et les myalgies évaluées au cours d'une entrevue post-opératoire.

$L$ installation ou la disparition du bloc neuromusculaire n'est pas influencée par l' intervalle entre les injections non plus que les myalgies past-opératoires. Les fasciculations étaient éliminées pour des interalles de 3 . 5 ou 7 minutes mais encore présentes pour des intervalles de $O$ ou I minute.

Il semble donc qu' un intervalle de trois minutes entre ladministration de dTc en de SCh est souhaitoble car des intervalles plus couris ne préviennem pas les fasciculations et des intervalles plus longs n'apportent aucun avantage additionnel. 